RESEARCH PAPER RP762

Part of Journal of Research of the National Bureau of Standards, Volume 14, February 1935

\title{
INDEX OF REFRACTION, DENSITY, AND THERMAL EXPANSION OF SOME SODA-ALUMINA-SILICA GLASSES AS FUNCTIONS OF THE COMPOSITION
}

\author{
By Conrad A. Faick, John C. Young, Donald Hubbard, and Alfred N. Finn
}

\section{ABSTRACT}

The index of refraction and density of 44 soda-alumina-silica glasses and the thermal expansion of 29 of the glasses were determined. The composition of the glasses, which varied from 1 to 10 percent alumina, 19 to 45 percent soda, and 50 to 78 percent silica, was determined by chemical analyses. The data are given in tabular form and graphs are presented from which the index of refraction, density, critical and softening temperatures, and the linear thermal expansion from room temperature to these temperatures can be predicted with reasonable accuracy for any glass in the series studied. The substitution of alumina for soda and silica in the proper ratios will give glasses having the same refractivity, density, and expansion as the original soda-silica glass; these ratios are approximately $1: 1.8,1: 1$, and $1: 1.5$, respectively. On the expansivity for a given temperature range the effect is about the same same as that of silica.

\section{CONTENTS}

Page

I. Introduction

II. Scope

III. Changes in the observed properties of the glasses with changes in composition

\section{INTRODUCTION}

Certain relations between chemical composition of some soda-limesilica glasses and their index of refraction, density, and thermal expansion are given in three previous reports. ${ }^{1}$ This report is the result of a study of similar relations for a series of soda-alumina-silica glasses.

In the first report the purpose of the general study was given, the method of making glasses was described, essential parts of the methods of chemical analysis and the condition of annealing were outlined, and the method of measuring index of refraction was detailed. Density determinations were discussed in the second report and the third report contained the necessary details for measuring thermal expansions.

\footnotetext{
1 C. A. Faick and A. N. Finn. The index of refraction of some soda-lime-silica glasses as a function of the composition. J. Am. Ceram. Soc. 14, 518 (1931). F. W. Glaze, J. C. Young, and A. N. Finn. The density of some soda-lime-silica glasses as a function of the composition. BS J. Research 9, 779 (1932) RP507. B. C. Schmid, A. N. Finn, and J. C. Young. Thermal expansions of some soda-lime-silica glasses as functions of the composition. BS J. Research 12, 421 (1934) RP667.
} 
Since the soda-alumina-silica glasses were made and handled in the same way as the soda-lime-silica glasses, descriptions of the methods involved will not be repeated in this report.

\section{SCOPE}

Forty-four glasses, containing approximately from 1 to 10 percent alumina, 50 to 78 percent silica, and 19 to 45 percent soda, were made and tested. The index of refraction for sodium light, and the density at approximately $20^{\circ} \mathrm{C}$ were determined for all the glasses; the thermal expansion and critical and softening temperatures were determined for only 29 of them. All the data obtained, including chemical composition, are given in table 1.

TABLE 1.-Compositions, observed indices of refraction, densities, critical and softening temperatures, and linear thermal expansions between the indicated temperatures ${ }^{1}$

\begin{tabular}{|c|c|c|c|c|c|c|c|c|c|}
\hline \multirow{2}{*}{ Glass no. } & \multicolumn{3}{|c|}{ Composition } & \multirow{2}{*}{$\begin{array}{c}\text { Index of } \\
\text { refraction } 2 \\
n_{D} \text { observed }\end{array}$} & \multirow{2}{*}{$\begin{array}{l}\text { Density }{ }^{2} \\
\text { observed } \\
\text { at } 20^{\circ} \mathrm{C}\end{array}$} & \multirow{2}{*}{$\begin{array}{l}\text { Critical } \\
\text { tempera- } \\
\text { ture }\end{array}$} & \multirow{2}{*}{$\begin{array}{l}\text { Linear } \\
\text { expansion } \\
25^{\circ} \mathrm{C} \text { to } \\
\text { critical } \\
\text { tempera- } \\
\text { ture }\end{array}$} & \multirow{2}{*}{$\begin{array}{l}\text { Softening } \\
\text { tempera- } \\
\text { ture }\end{array}$} & \multirow{2}{*}{$\begin{array}{l}\text { Linesr } \\
\text { expansion } \\
25^{\circ} \mathrm{C} \text { to } \\
\text { softening } \\
\text { tempera- } \\
\text { ture }\end{array}$} \\
\hline & $\mathrm{SiO}_{2}$ & $\mathrm{Na}_{2} \mathrm{O}$ & $\mathrm{Al}_{2} \mathrm{O}_{3}$ & & & & & & \\
\hline \multirow{2}{*}{$\begin{array}{l}101 \ldots \ldots \\
102 \\
103\end{array}$} & \multirow{2}{*}{$\begin{array}{c}\% \\
50.32 \\
50.57\end{array}$} & \multirow{2}{*}{$\begin{array}{c}\% \\
46.82 \\
42.43\end{array}$} & \multirow{2}{*}{$\begin{array}{c}\% \\
2.86 \\
7.00\end{array}$} & \multirow{2}{*}{$\begin{array}{l}\text { 1. } 5162(-1) \\
1.5154(-2)\end{array}$} & 2. $5605(+15)$ & ${ }^{\circ} \mathrm{O}$ & $\mu / \mathrm{cm}$ & ${ }^{\circ} \mathrm{C}$ & $\mu / \mathrm{cm}$ \\
\hline & & & & & 2. $5495(+10)$ & $447(+2)$ & 82. $0(-1)$ & $489(+2)$ & $94.5(0)$ \\
\hline 103 & 50.86 & 42.43 & 6.71 & 1. $5155(+3)$ & 2. $5484(+5)$ & $447(+3)$ & & $492(+7)$ & $98.5(+4)$ \\
\hline & 50.89 & 39.54 & 9.57 & 1. $5150(+2)$ & $2.5410(-3)$ & $455(0$ & 82.0 & 501( & $99.0(+6)$ \\
\hline & $\begin{array}{l}50.95 \\
55.25\end{array}$ & $\begin{array}{l}44.17 \\
34.92\end{array}$ & $\begin{array}{l}4.88 \\
9.83\end{array}$ & & 2. $5533(+13)$ & $\begin{array}{l}435(-1) \\
477(+4)\end{array}$ & $\begin{array}{l}84.2(0) \\
76.0(-\end{array}$ & 472( & $94.8(0)$ \\
\hline $\begin{array}{l}106- \\
107-\end{array}$ & $\begin{array}{l}55.25 \\
55.56\end{array}$ & $\begin{array}{l}34.92 \\
37.50\end{array}$ & $\begin{array}{l}9.83 \\
6.94\end{array}$ & $\begin{array}{l}\text { 1. } 5116(+2) \\
1.5120(-1)\end{array}$ & $\begin{array}{l}\text { 2. } 5182(-5) \\
2.5259(+11)\end{array}$ & $\begin{array}{l}477(+4) \\
457(0)\end{array}$ & $\begin{array}{l}76.0(- \\
77.2(0\end{array}$ & $\begin{array}{l}517(0) \\
501(+1)\end{array}$ & $\begin{array}{l}86.2(-2) \\
90.5(+2)\end{array}$ \\
\hline & 55.66 & 34. 66 & 9.68 & 1. $5110(-2)$ & 2. $5163(-7)$ & & & & \\
\hline & 55.80 & 41.32 & $\begin{array}{l}2.88 \\
4.83\end{array}$ & 1. $5130(+2)$ & 2. $5364(+22)$ & $440(+2)$ & $79.0(0)$ & $484(+9)$ & $91.5(0)$ \\
\hline & $\begin{array}{l}55.86 \\
60.45\end{array}$ & $\begin{array}{l}39.23 \\
29.71\end{array}$ & $\begin{array}{l}4.83 \\
9.84\end{array}$ & $\begin{array}{l}1.5124(0) \\
1.5072(+1)\end{array}$ & $\begin{array}{l}\text { 2. } 5304(+16) \\
2.4897(-12)\end{array}$ & & 78.9 & $492(+3)$ & $(+4)$ \\
\hline 12 & 60.68 & 34.46 & 4.86 & 1. $5088(+2)$ & 2. $5032(-8)$ & $465(+3)$ & 74. $0(0)$ & $504(0)$ & $86.2(+2)$ \\
\hline & $\begin{array}{l}60.76 \\
60.78\end{array}$ & $\begin{array}{l}36.42 \\
38.13\end{array}$ & $\begin{array}{l}2.82 \\
1.09\end{array}$ & $\begin{array}{l}\text { 1. } 5092(+1) \\
\text { 1. } 5094(0)\end{array}$ & 2. $5111(+19)$ & $455(+2)$ & $75.4(-1)$ & $491(+1)$ & $86.0(0)$ \\
\hline & 60.88 & 29.53 & 9.59 & 1. $5070(+2)$ & 2. $4891(-4)$ & $495(+2)$ & $68.8(-1)$ & $530(-7)$ & $79.4(-2)$ \\
\hline & $\begin{array}{l}60.97 \\
64.78\end{array}$ & $\begin{array}{l}32.46 \\
34.20\end{array}$ & $\begin{array}{l}6.57 \\
1.02\end{array}$ & $\begin{array}{l}\text { 1. } 5073(-5) \\
\text { 1. } 5059(-2)\end{array}$ & $\begin{array}{l}2.4977(+3) \\
2.4916(-13)\end{array}$ & $458(+1$ & & & \\
\hline & 65.10 & 24.94 & 9.96 & 1. $5032(+1)$ & $\begin{array}{l}\text { 2. } 4910(-15) \\
2.4615(-5)\end{array}$ & 510 & 65. $2(+1)$ & 561 & (0) \\
\hline & 65.70 & 29.55 & 4.75 & 1. $5049(+7)$ & $2.4749(-6)$ & $475(-3)$ & 70.4 & $530(+12)$ & 84. $6(+8)$ \\
\hline & 65.88 & 24.69 & 9.43 & 1. $5025(-1)$ & 2. $4580(+1)$ & $505(-$ & & -10) & $72.0(-3)$ \\
\hline $\begin{array}{l}121 . \\
122\end{array}$ & $\begin{array}{l}65.90 \\
65.92\end{array}$ & $\begin{array}{l}31.23 \\
31.67\end{array}$ & $\begin{array}{l}2.87 \\
2.41\end{array}$ & $\begin{array}{l}\text { 1. } 5052(+6) \\
1.5047(0)\end{array}$ & $\begin{array}{l}2.4830(+25) \\
2.4814(-3)\end{array}$ & $470(+3)$ & $72.0(+3)$ & $000(8)$ & $85.2(+7)$ \\
\hline & 66.36 & 31.61 & 2.03 & 1. $5050(+5)$ & $2.4805(+3)$ & $470(+6)$ & 67. $2(-2)$ & $517(+14)$ & $83.0(+5)$ \\
\hline & 67.21 & 28.34 & 4.45 & 1. $5026(-4)$ & $2.4653(-13)$ & & & & \\
\hline $125_{-}$ & $\begin{array}{l}67.75 \\
68.10\end{array}$ & $\begin{array}{l}29.30 \\
25.15\end{array}$ & $\begin{array}{l}2.95 \\
6.75\end{array}$ & $\begin{array}{l}1.5030(-3) \\
1.5018(+3)\end{array}$ & $\begin{array}{l}2.4683(+1) \\
2.4539(+11)\end{array}$ & & 63.0 & & \\
\hline & 68.78 & 25.45 & 5.77 & 1. $5006(-1)$ & $2.4534(+18)$ & & & & \\
\hline & 69.99 & 29.04 & 0.97 & 1. $5020(+4)$ & 2. $4612(+10)$ & $470(0)$ & $69.6(+4)$ & $515(+10)$ & $81.5(+7)$ \\
\hline & 70.11 & 27.86 & 2.03 & 1. $5015(-1)$ & $2.4572(+17)$ & $476(+2)$ & 65.13 & $520(+8)$ & $76.5(+4)$ \\
\hline & $\begin{array}{l}70.30 \\
70.63\end{array}$ & $\begin{array}{l}24.84 \\
24.45\end{array}$ & $\begin{array}{l}4.86 \\
4.92\end{array}$ & $\begin{array}{l}1.5003(+3) \\
1.5000(+4)\end{array}$ & $\begin{array}{l}2.4445(-1) \\
2.4428(+7)\end{array}$ & $\begin{array}{l}490(0) \\
490(-2)\end{array}$ & $\begin{array}{l}61.0(-1) \\
61.0(0)\end{array}$ & $\begin{array}{l}535(-2) \\
541(+3)\end{array}$ & $\begin{array}{l}70.4(-1) \\
76.9(+6)\end{array}$ \\
\hline & 70.84 & 26.31 & 2.85 & $1.5007(+6)$ & 2. $4509(+34)$ & & & & \\
\hline & 70.88 & 22.63 & 6.49 & $1.4988(+1)$ & $2.4343(-11)$ & 500( & 57.7 & $553(0$ & $69.5(0)$ \\
\hline & $\begin{array}{l}71.08 \\
73.15\end{array}$ & $\begin{array}{l}19.60 \\
25.87\end{array}$ & 9.32 & $1.4970(-2)$ & $2.4214(-10)$ & & 54. $0(+1)$ & & \\
\hline & 73.81 & 21.50 & 4.69 & $1.4957(-2)$ & $2.4181(-5)$ & $502(+2)$ & $53.0(-2)$ & $552(+4)$ & $64.0(-2)$ \\
\hline & 74.75 & 24.27 & 0.98 & $1.4970(+3)$ & $2.4277(+7)$ & & . & - & - \\
\hline & $\begin{array}{l}74.88 \\
74.95\end{array}$ & $\begin{array}{l}22.12 \\
23.98\end{array}$ & $\begin{array}{l}3.00 \\
1.07\end{array}$ & $\begin{array}{l}1.4955(-2) \\
1.4960(+1)\end{array}$ & $\begin{array}{l}2.4162(-1) \\
2.4234(-13)\end{array}$ & $481(-4)$ & $60.2(+2)$ & $531(+9)$ & $748(+$ \\
\hline & 74.98 & 23.02 & 2.00 & 1. $4952(-3)$ & $2.4186(-16)$ & $490(+2)$ & $57.7(+1)$ & $539(+9)$ & \\
\hline & 75.21 & 19.67 & 5.12 & $1.4934(-5)$ & $2.4025(-1)$ & $502(-2)$ & $48.2(-2)$ & $550(-5)$ & $54.8(-9)$ \\
\hline & 75.61 & $\begin{array}{l}19.70 \\
21.54\end{array}$ & $\begin{array}{l}4.82 \\
2.85\end{array}$ & 1. $4949(+4)$ & 2. $4117(+20)$ & $495(0)$ & $54.5(+1)$ & $539(0)$ & $66.0(+2)$ \\
\hline & 77.71 & 21.36 & 0.93 & $1.4926(-2)$ & $2.4013(+31)$ & & & & \\
\hline
\end{tabular}

1 The figures in parentheses, when subtracted from the observed values, give computed values, or those obtained from figs. $1,2,3$, and 4 .

The parenthetical figures in these two columns have been multiplied by $10^{4}$. 


\section{CHANGES IN THE OBSERVED PROPERTIES OF THE GLASSES WITH CHANGES IN COMPOSITION}

Correlation of the measured properties and composition of the glasses, as shown in figures 1 to 4 , was based on the procedure used

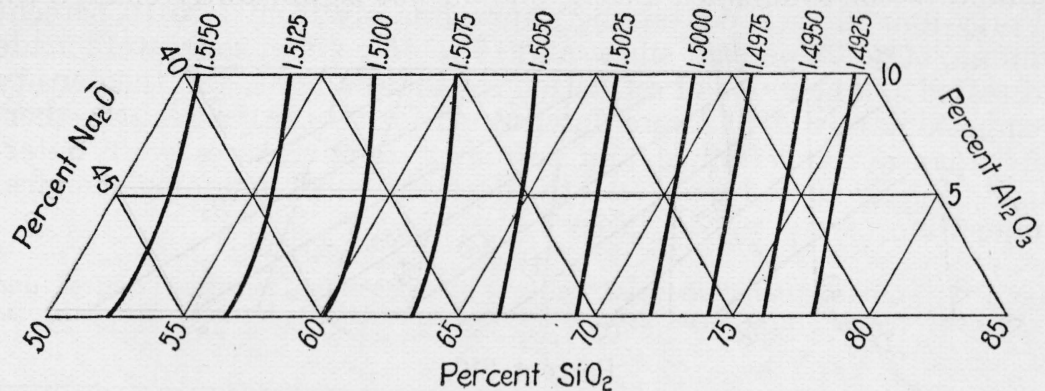

FIGURE 1.-Relation between composition and index of refraction of some sodasilica-alumina glasses.

for density-composition relations described in the following paragraph. $^{2}$

The data were first plotted on a triordinate diagram according to their compositions. Then lines of constant density were obtained by first interpolating graphically between several pairs of neighboring points so chosen as to be near to a trial constant density value, and then sketching the lines through the interpolated points. The inter-

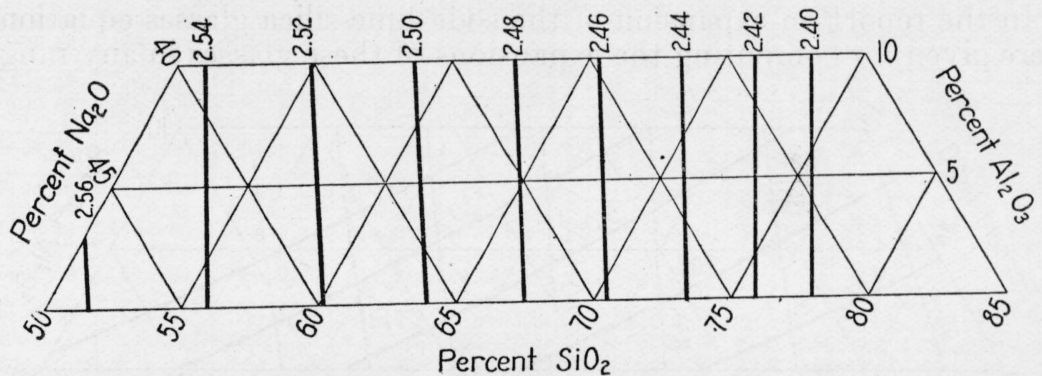

Figure 2.-Relation between composition and density of some soda-silica-alumina glasses.

sections of these lines with the silica-soda base line were established from the published data for that series of glasses.

The effects of changes in composition on index of refraction, density, critical temperature, and total expansion from room temperature to the critical temperature, and on softening temperature and the total expansion from room temperature to the softening temperature are indicated in figures $1,2,3$, and 4 , respectively.

2 The following type of correlation was also worked out, but is not reported here. An algebraic solution, based on the previously reported factors for silica and soda, was used to determine factors for alumina, and from these factors constant density and refractivity lines were drawn on triordinate diagrams. This procedure necessarily yielded "break lines" (discussed in the report on density of the soda-lime glasses) running obliquely across the diagrams, dividing the field into four areas, corresponding to the number of silica-soda groups. Very little weight could be attached to the locations of these lines, however, owing partly to the limited amount of alumina present and partly to the fact that the total changes in the magnitude of the properties measured were relatively small. 
The difference between the observed value of any of the properties of the alumina glasses and the value read from the appropriate figure is given parenthetically in table 1 . Similar differences for the alumina-free glasses were presented in the reports previously cited.

It can be shown from a study of the graphs that additions of alumina to the soda-silica glasses should not significantly change the

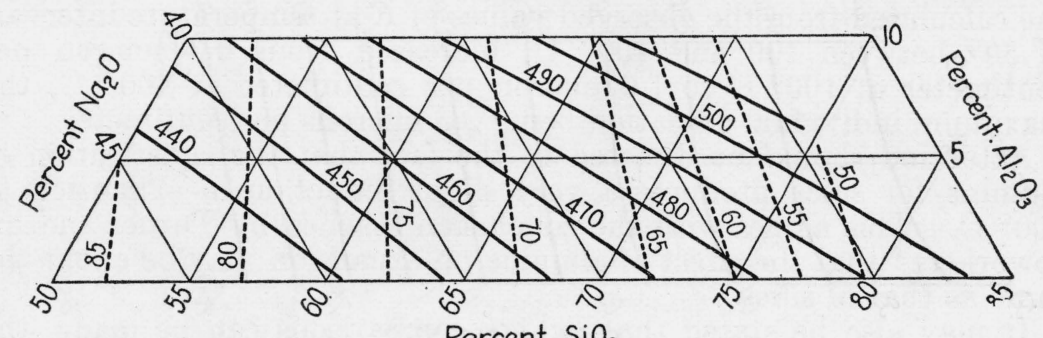

Percent $\mathrm{SiO}_{2}$

FigURE 3.-Relation between composition of some soda-silica-alumina glasses and critical temperatures (solid lines) and also linear expansions (broken lines) from $25^{\circ} \mathrm{C}$ to those temperatures.

Temperatures are given in ${ }^{\circ} \mathrm{C}$ and expansions in $\mu / \mathrm{cm}$.

refractivity, density, or expansion to the softening point if, for the amount of alumina added, the silica and soda are reduced in the ratio $1: 1.8,1: 1$, or $1: 1.5$, respectively; the expansion to the critical temperatures changes, however, the ratio of substitution in the highsilica region being about 1:0.22 and in the low-silica region about $1: 1$.

In the report on expansion of the soda-lime-silica glasses equations were given for computing the expansions of these glasses in any range

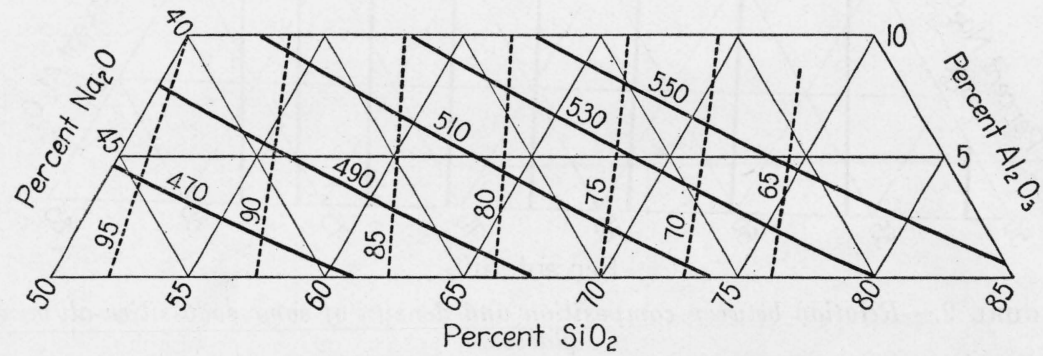

FIGURE 4.-Relation between composition of some soda-silica-alumina glasses and softening temperatures (solid lines) and also linear expansions (broken lines) from $25^{\circ} \mathrm{C}$ to those temperatures.

Temperatures are given in ${ }^{\circ} \mathrm{C}$ and expansions in $\mu / \mathrm{cm}$.

between 25 and $450^{\circ} \mathrm{C}$. Following the procedure used for evaluating the constants in those equations, constants were computed from the data on the soda-alumina-silica glasses, with the following results:

$$
\begin{aligned}
E & =a A+b B+d D \\
a & =0.00043 t-0.0000003 t^{2} \\
b & =0.00274 t+0.0000035 t^{2} \\
d & =0.00001 t-0.0000003 t^{2}
\end{aligned}
$$

in which $E$ is the linear thermal expansion, in microns per centimeter, between $25^{\circ} \mathrm{C}$ and any temperature $T$ less than $400^{\circ} \mathrm{C}, t=T-25$, 
$A, B$, and $D$ are the percentages of silica, soda, and alumina, respectively, and $a, b$, and $d$ are the indicated functions of temperatures. Although these constants were computed without respect to those previously reported ${ }^{3}$ it is noteworthy that the expansions for the sodasilica glasses computed from either set of constants for silica and soda are about the same. The average deviation (with approximately equal distribution between positive and negative values) of the calculated from the observed values of $E$ at temperature intervals of $50^{\circ}$ between 100 and $400^{\circ} \mathrm{C}$, increased from 0.3 micron per centimeter at $100^{\circ} \mathrm{C}$ to 1.0 micron per centimeter at $400^{\circ} \mathrm{C}$, the maximum individual deviation being 2.5 microns per centimeter.

Attention should be directed to the fact that the substitution of alumina for silica produces a very slight reduction in expansion to $400^{\circ} \mathrm{C}$. This agrees with the conclusion reached by Turner and his coworkers ${ }^{4}$ that the effect of alumina on expansion may be about the same as that of silica.

It may also be stated that, where comparisons can be made, the refractivity and density of the alumina glasses reported by us agree reasonably well with the results reported by Turner and his coworkers ${ }^{5}$ if the small amounts of impurities in their glasses are taken into consideration.

Washington, August 27, 1934.

3 The previously reported values are:

$a=0.00036 t-0.00000036 t^{2}$

$b=0.00245 t+0.0000046 t^{2}$

4 S. English and W. E. S. Turner. The thermal expansion of glasses containing aluminium. J. Soc. Glass Tech. 5, 183 (1921); and Violet Dimbleby, S. English, F. W. Hodkin, and W. E. S. Turner. Further investigations of the influence of alumına on the properties of glass. J. Soc. Glass Tech. 8, 173 (1924)

s. R. Clarke and W. E. S. Turner. Note on some optical properties of the sodium-aluminium trisilicate glasses. J. Soc. Glass Tech. 5, 119 (1921); and S. English and W. E. S. Turner. The density of glasses containing aluminium. J. Soc. Glass Tech. 5, 277 (1921). 